\title{
DOR dan Drama Keadilan (Analisis Sosiologi Sastra)
}

\author{
Khothibul Umam \\ Fakultas Ilmu Budaya, Universitas Diponegoro \\ khothibul.umam@live.undip.ac.id
}

\begin{abstract}
The study of play scripts is one of the rare literary studies. One reason is because the object is very rare. The highly productive Indonesian play script writer is Putu Wijaya. Putu Wijaya wrote many stories with many themes, one of which was titled DOR, which raised social and justice themes. The theory used to analyze DOR is the sociology of literature with the help of psychology and law science through literature study with the method of reading, listening and note taking. In DOR, there are various kinds of character clashes between characters in responding to a case. Justice that tries to be sought in the narrative of this play always collides with various problems, where the premise becomes a kind of reflection on social phenomena that occur in the real world. Even though it was written decades ago, DOR still feels relevant to the condition of society, especially its relation to the world of law enforcement and the search for justice, which is increasingly bleak and unclear. As a work of art, DOR is capable of photographing various kinds of legal world phenomena with all its cross-clashes. The clash of character or character really represents all the complexities of legal problems in Indonesia. Where various interests take part in determining the results of justice seeking.
\end{abstract}

Keywords : Play; Putu Wijaya; justice; sociology of literature; character.

\section{Intisari}

Kajian terhadap naskah lakon adalah salah satu penelitian sastra yang jarang dilakukan. Salah satu alasannya adalah karena objeknya yang sangat langka. Penulis naskah lakon Indonesia yang sangat produktif adalah Putu Wijaya. Putu Wijaya menulis banyak lakon dengan banyak tema, salah satunya adalah yang berjudul $D O R$ yang mengangkat tema sosial dan keadilan. Teori yang dipakai untuk menganalisis $D O R$ adalah sosiologi sastra dengan bantuan ilmu psikologi dan ilmu hukum melalui studi pustaka dengan metode baca, simak dan catat. Dalam DOR ditemukan berbagai macam benturan karakter antar tokoh dalam menyikapi sebuah kasus. Keadilan yang coba dicari dalam narasi lakon ini selalu terbentur pada berbagai masalah, di mana premis tersebut menjadi semacam refleksi atas fenomena sosial yang terjadi di dunia nyata. Meskipun ditulis berpuluh tahun yang lalu, DOR masih terasa relevan dengan kondisi masyarakat, terutama kaitannya dengan dunia penegakan hukum dan pencarian keadilan, yang semakin suram dan tidak jelas. Sebagai sebuah karya seni, DOR mampu memotret berbagai macam fenomena dunia hukum dengan dengan segala silang sengkarutnya. Perbenturan watak atau karakter tokoh betul-betul mewakili segala kompleksitas permasalahan hukum yang ada di Indonesia. Di mana berbagai kepentingan turut andil dalam penentuan atas hasil-hasil pencarian keadilan.

Kata kunci : Drama; Putu Wijaya; keadilan; sosiologi sastra; watak. 


\section{Pendahuluan}

Drama ialah kisah lakuan (kisah yang dilakonkan). Asal-usul drama muncul di Yunani Kuno kurang lebih 6000 tahun sebelum Masehi. Istilah drama berasal dari kata draomai yang artinya berbuat menirukan suatu kejadian (Eddy, 1991:59). Sebagai salah satu genre karya sastra, drama mengungkapkan dan mengisahkan ceritanya melalui dialog (percakapan) tokohtokohnya (Eneste, 1994:28).

Menurut Waluyo, drama ada empat jenis, yaitu: tragedi, komedi, melodrama, dan dagelan. Di antara tragedi dengan komedi terdapat klasifikasi tragikomedi, tetapi klasifikasi tersebut dapat dibicarakan dalam menelaah tragedi dan komedi (2002:38). Selain itu masih ada beberapa aliran seperti klasik, romantik, realisme, ekspresionisme, naturalisme, dan eksistensialisme.

Di Indonesia pun, drama berkembang dengan demikian pesatnya, baik naskah maupun pementasan. Perkembangan drama Indonesia sudah dimulai jauh-jauh hari sejak zaman penjajahan Belanda. Kemudian dengan dibukanya ATNI (Akademi Teater Nasional Indonesia) dan ASDRAFI (Akademi Seni Drama dan Film Indonesia), yang banyak menelurkan seniman-seniman drama, teater dan film Indonesia, perkembangan drama di Indonesia menjadi sangat mengesankan. Nama-nama seperti Rendra, Arifin C. Noer, Putu Wijaya, Teguh Karya, Nano Riantiarno, serta banyak nama lain yang menghiasi dunia teater Indonesia.

Salah satu nama yang menonjol adalah Putu Wijaya dengan kelompoknya, Teater Mandiri. Dia pernah bergabung dengan Rendra dalam Bengkel Teater. Teater Mandiri sendiri anggotanya sebagian besar adalah karyawan Tempo dan Zaman. Naskah drama karya Putu Wijaya biasanya adalah naskah drama yang memang dibuat dengan tujuan pemanggungan atau yang biasa disebut teks drama pentas. Petunjuk-petunjuk pemanggungannya dibuat untuk membangun suasana teatrikal. Beda dengan drama baca, drama pentas suasana teatrikalnya lebih dominan (Aston, 1991: 12). Naskah-naskah Putu Wijaya sangat eksperimental. Salah satu eksperimen di awal-awal Teater Mandiri adalah dengan membuat tokoh dan penokohan dengan tidak jelas, baik dalam nama, sosok, dan karakter (lihat Waluyo, 2002:84).

Selanjutnya penulis akan menganalisis salah satu naskah karya Putu Wijaya yang berjudul DOR. Dalam kata pengantar karyanya, disebutkan bahwa karyanya ini 
mengetengahkan masalah seputar dunia hokum dan rumitnya sebuah kasus karena konflik kepentingan (Wijaya, 1993:5). Para tokoh dalam DOR menjalani sisi ambiguitas dalam watak dan karakternya. Terbawa oleh narasi cerita dan konflik yang keras dan buntu sekaligus anekdotal. Naskah ini selesai ditulis tanggal 24 Januari 1979 dan dipentaskan pertama kali 2131 Maret 1979.

\section{Metode Penelitian}

Naskah lakon DOR karya Putu Wijaya mengangkat tema sosial dengan komplikasi karakter masing-masing tokoh dalam pembentukan narasi cerita. Maka pendekatan yang relevan digunakan adalah sosiologi dan psikologi.

Selain itu, sebagai ilmu multidisiplin, maka perlu pula dipakai beberapa ilmu bantu di luar sosiologi dan psikologi sesuai dengan kebutuhan kajian, misalnya ilmu hukum. Untuk menganalisis $D O R$, pendekatan yang dipakai adalah sosiologi karya sastra yang menilai teks sebagai cermin masyarakat. Telaah teks tidak didahului oleh penelitian struktur teks tetapi langsung pada aspek sosial dan psikologi karakter pada tokoh dan konteksnya dengan tema keadilan. Seluruh data untuk penelitian ini dikumpulkan melalui studi pustaka. Hasil analisis kemudian akan ditampilkan dalam bentuk deskriptif, yaitu menampilkan kenyataan yang ditemukan dalam teks apa adanya.

\section{Hasil dan Pembahasan}

\section{Keadilan yang Bingung}

Sebuah karya drama mempunyai banyak sekali struktur. Sebagai salah satu genre sastra, naskah drama dibangun oleh struktur fisik (kebahasaan) dan struktur batin (semantik, makna) (Waluyo, 2002:6). Biasanya struktur drama terdiri dari alur dan pengaluran; tokoh dan penokohan; cakapan; latar dan pelataran; tema cerita; dan amanat. Struktur-struktur tersebut satu sama lain saling mendukung dan tidak bisa dipisahkan.

Drama sendiri mempunyai struktur yang khas dan beda dibandingkan dengan genre sastra lain, semisal puisi atau prosa. Dalam drama ada unsur spectacle, yaitu bagian yang yang secara langsung dilihat oleh penonton (spectator), serta pengalaman inderawi, termasuk segala 
hal yang didengar (dialog/bunyi), dilihat mata, dan apapun yang dirasakan melalui seluruh alat visual serta pengalaman aural (lihat Dewojati, 2010: 158-159).

Namun di dalam menganalisis karya drama, kita dapat menganalisis salah satu struktur tersebut dengan tidak mengabaikan struktur yang lain. Hal ini dimungkinkan karena masingmasing struktur drama mepunyai kerangka sendiri-sendiri. Selanjutnya penulis akan membahas tentang penokohan dan perwatakan, karena setelah sebuah karya drama dipentaskan, para tokohlah yang memegang peran di atas pentas.

Sebagai subyek yang menggerakkan peristiwa-peristiwa cerita, tokoh tentu saja dilengkapi dengan watak atau karakteristik tertentu. Watak adalah ciri, sifat dan sikap yang dimiliki oleh setiap tokoh dalam karya sastra baik cerita maupun lakon (Eddy, 1991:215). Watak inilah yang menggerakkan tokoh untuk melakukan perbuatan tertentu sehingga cerita menjadi hidup.

Berdasarkan peranannya terhadap jalan cerita, terdapat tiga tokoh, yaitu:

1. Tokoh Protagonis, yaitu tokoh yang mendukung cerita.

2. Tokoh Antagonis, yaitu tokoh penentang cerita.

3. Tokoh Tritagonis, yaitu tokoh pembantu, baik untuk tokoh protagonis maupun tokoh antagonis (Waluyo, 2002:16).

Sedangkan berdasarkan peranannya dalam lakon serta fungsinya, terdapat tokoh-tokoh sebagai berikut:

1. Tokoh sentral, yaitu tokoh-tokoh yang paling menentukan gerak lakon, yakni tokoh protagonis dan tokoh antagonis.

2. Tokoh utama, yaitu tokoh pendukung atau penentang tokoh sentral, yakni tokoh tritagonis.

3. Tokoh pembantu, yaitu tokoh-tokoh yang memegang peran pelengkap atau tambahan dalam mata rangkai cerita (Waluyo, 2002:16).

Di dalam DOR, semua tokohnya adalah manusia, untuk membedakannya mereka diberi nama atau jabatan. Tetapi ada pula yang tidak diberi nama dan jabatan, seperti tokoh "seseorang". Secara lengkap, kesemua tokoh dalam DOR adalah: Hakim, Pelayan, Tamu I, Tamu-tamu, Jaksa, Pembela, Pemuda/Ali, Saksi (5 orang perempuan), Yulia/Pacar Ali, Inem, Para Pelacur, Nyonya Gubernur, Gubernur, Sobat/Anak, dan Lan Fa. 
Sesuai dengan tema yang diangkat, yaitu keadilan, maka tokoh utama dalam lakon ini adalah Hakim. Sejak awal cerita, Hakim selalu ditampilkan dan yang paling banyak menampilkan perubahan karakter. Dari mulai bingung, cuek, peduli, lemah, adil, tegas, hingga tak bisa berbuat apa-apa. Karakter Hakim senantiasa didampingi oleh Pelayan yang selalu setia melayani hingga kadang malah keblabasan.

Hakim dan Pelayan dalam naskah DOR menempati posisi sebagai tokoh protagonis. Kedua karakter ini sangat berperan sebagai pendukung cerita. Merekalah yang paling menentukan gerak lakon dan memulai proses perputaran lakon. Peran mereka sangat kentara, terutama pada awal cerita, seperti kutipan di bawah ini:

Pelayan : Tajuk Sinar Sore penuh kecaman. (membaca) Keadilan sangat supel dan luwes. Ia membengkok seperti lengkungan arit. Ia menggeliat seperti ular. Ia berakrobat seperti gadis-gadis plastik.

Hakim : Ia diintai !

Pelayan : Kompas di dalam pojoknya berkata: Keadilan bersenjata, kebijaksanaan memihak, konsepsi tua yang terhormat, hakim kikuk, itulah ciri pengadilan kini (hlm. 7).

Kutipan di atas sangat tepat sekali sebagai pembuka, karena menyiratkan tentang apa yang akan dikisahkan kemudian, yaitu tentang keadilan. Selanjutnya, Kedua tokoh inilah yang kemudian banyak ditentang oleh tokoh lain, sehingga menimbulkan konflik perihal keadilan.

Para tokoh penentang cerita ini ditampilkan pula sejak awal, tetapi bukan merupakan tokoh antagonis, lebih kepada tokoh tritagonis. Seperti tokoh Tamu pada kutipan berikut:

Tamu : Anda sudah lapuk. Anda tak mengerti keinginan modern. Anda tersesat dalam kehormatan dan cita-cita yang tua. Anda menghambat langkah kami, anda menentang kami dengan kekuasaan yang anda punyai sekarang. Anda penakut! Dan semua itu anda sadari serta diam-diam menentangnya dalam hati! Tetapi lacur, anda tak mempunyai keberanian. Pengorbanan memang permainan muda-muda saja, mereka yang belum punya tanggungan.

Pelayan : Silahkan pergi!

Tamu : Tidak.

Pelayan mendorong tamu itu pergi. Mereka bergumul. Pelayan itu mudah dikalahkan (hlm. 10). 
Dalam kutipan di atas terlihat jelas sekali pertentangan antara Hakim/Pelayan dan Tamu. Namun kedudukan Tamu di sini hanyalah sebatas tokoh tritagonis yang mengantarkan dan memegang peran pelengkap dalam mata rangkai cerita.

Lebih lanjut, tokoh antagonis yang paling berperan dalam lakon ini adalah Yulia, Nyonya Gubernur dan Gubernur. Yulia, sebagai kekasih Ali, calon menantu Gubernur, dan orang yang paling menderita jika Ali dihukum, berperan sebagai penentang utama kebijaksanaan Hakim. Bahkan ia rela mengeluarkan uang dalam rangka menyuap Pelayan, seperti kutipan berikut:

$\begin{array}{ll}\text { Yulia } & \text { (melemparkan dompet) Nih! Keadilan yang lebih besar } \\ & \text { masih banyak yang harus dibela. Bijaksana sedikit untuk } \\ & \text { kecelakaan-kecelakaan kecil. Maklum anak muda. (Lampu } \\ & \text { mati, wanita itu lenyap) } \\ \text { Pelayan } & :(\text { mengambil dompet) Heee! (hlm. 18-19). }\end{array}$

Nyonya Gubernur pun bertindak serupa dengan menyuruh Inem agar Pelayan mengambil surat Hakim (hlm. 42). Sedangkan Gubernur hanya berada di bawah pengaruh istrinya.

Untuk tokoh tritagonis yang berperan sebagai pembantu protagonis adalah: Saksi, Jaksa, Para Pelacur, Sobat, dan Lan Fa. Sedangkan yang berperan sebagai pembantu antagonis, yaitu: Pembela, Tamu, dan Inem.

Selanjutnya untuk perwatakan dapat dipaparkan sebagai berikut:

1. Hakim, berwatak ragu-ragu, kurang tegas, selalu berubah, agak bingungan, sakit-sakitan, namun pada akhirnya berani mengambil keputusan, lelaki.

2. Pelayan, berwatak penjilat, tipe Asal Bapak Senang, plin-plan, kalah oleh wanita, namun berubah pada saat akhir, lelaki.

3. Yulia, berwatak menghalalkan segala cara, sangat cinta pada kekasih, keras, kejam, cantik, muda.

4. Nyonya Gubernur, berwatak dominan, sangat sayang kepada keluarga (bahkan berlebihan), pandai, kasar, licik.

5. Gubernur, berwatak kalem, didominasi istri, frustasi, kejam pada saat akhir.

6. Tamu, berwatak ngotot, pandai berkelahi, penuntut.

7. Jaksa, berwatak teliti, cerdas.

8. Pembela, berwatak pintar, pandai berkata-kata. 
9. Pemuda/Ali, berwatak kompromis, jujur, berani mengakui kesalahan

10. Saksi, berwatak cerewet, pandai bercerita.

11. Inem, berwatak penjilat, pandai merayu, licik.

12. Para Pelacur, berwatak reaksioner, toleran.

13. Sobat/Anak, berwatak bijaksana, pemberi pandangan, pekerja keras, teman Hakim semasa kecil.

14. Lan Fa, berwatak lembut, patut dikasihani, tidak berani bersikap, cantik.

Dalam drama ini kebingungan demi kebingungan terus terjadi dan saling berkelindan. Hal ini memang sudah menjadi ciri khas Putu Wijaya dalam setiap dramanya. Kebingungan terhadap pencarian keadilan adalah ramuan yang pas untuk merefleksikan kondisi sosial yang ada. Betapa sebuah kasus hukum bisa menjadi simpang siur perihal keadilan dan jalannya persidangan karena masing-masing tokoh mempunyai kepentingan yang bertolak-belakang satu sama lain. DOR menjadi semacam kritik terhadap penegakan hukum yang kerap pilih kasih. Ibarat kata seperti pisau yang selalu tajam ke bawah dan tumpul ke atas.

Kebingungan dalam watak, jalan cerita dan plot membuat $D O R$ lebih menggigit dan mempunyai unsur teror mental. Eksploitasi tema kebingungan dalam pencarian keadilan ini lambat laun menjelma menjadi teror. Dalam DOR teror tidak semata-mata hadir dalam bentuk yang mengerikan. Teror bisa berubah bentuk menjadi sebuah anekdot.

Perubahan bentuk menjadi anekdot (atau satir) ini bukanlah sebuah kebetulan untuk melucu belaka. Hal-hal lucu, remeh, aneh, kadangkala tidak masuk akal, untuk mengagetkan, mencubit, menarik perhatian, mengganggu, meneror orang supaya terhenti sebentar, lalu berpikir dan mungkin ingat kembali bahwa dia juga manusia seperti orang lain (Wijaya, 1982).

Bagi Putu Wijaya, menulis adalah menggorok leher. Leher sendiri atau milik siapa saja, tetapi tanpa menyakiti yang bersangkutan, bahkan kalau bisa tanpa diketahui. Ini semacam pencurian, kucing-kucingan, akal-akalan, kadangkala dengan ngumpet-ngumpet, bila perlu menghapus jejak sama sekali (Wijaya, 2011)

Perkara teror mental yang sudah menjadi ciri dari Putu Wijaya ini juga tidak bisa dilepaskan dari gaya drama Putu Wijaya yang cenderung menggunakan gaya ungkap stream of consciousness alias arus kesadaran. Istilah ini semacam gaya penceritaan pengenalan 
tokohnya secara langsung, tanpa bantuan narator atau pencerita maupun pengarang. Sering pula Putu Wijaya menggunakan plot yang nonlinear, bahkan terkesan melompat-lompat tanpa ada kaitan peristiwa satu dengan peristiwa lainnya (Dewojati, 2010: 137).

Dengan resep teror mental dan dunia hukum yang benar-benar tidak ideal penegakannya di Indonesia, ditambah relevansinya hingga masa sekarang, DOR menjadi sebuah refleksi dan kritik atas sebuah bangsa yang bernama Indonesia. Dari sini dapat kita ketahui bagaimana DOR ditulis dan dibangun. Penuh dengan kerumitan, kejutan, gangguan, baik secara teks maupun jika diolah dalam pemanggungan.

\section{Eksperimen tentang Pencarian Keadilan}

Sebagaimana yang telah kita ketahui, Putu Wijaya terkenal dengan karyanya yang bersifat eksperimental, tidak terkecuali dengan karyanya ini. Dalam DOR, Putu menampilkan eksperimen-eksperimen, berupa pembahasan tentang tema hukum (yang jarang dikaji secara khusus oleh teaterawan Indonesia), maupun berupa eksplorasi artistik.

Sedikit informasi ketika DOR dipentaskan oleh Teater Mandiri, Putu dibantu Roedjito sebagai penata artistiknya. Roedjito jugalah yang mengusulkan agar dalam pementasan itu, posisi duduk Hakim membelakangi penonton, supaya menimbulkan efek yang berbeda bagi penonton dan member kesan misterius seperti di dalam naskah. Putu Wijaya mencatatnya dalam "Warisan Roedjito" (Dipayana, 2004). Menurut Roedjito: "Kebalikan total dari kebenaran itu sendiri adalah kebenaran yang lain. Demikian juga semua kesalahan atau kekeliruan. Kebalikan total dari sebuah kesalahan dan kekeliruan adalah kesalahan dan kekeliruan yang lain. Dengan $D O R$, Putu Wijaya seakan menahbiskan jika keadilan pun tetap punya wajah. Tergantung dari siapa yang berkuasa dan mau diapakan kekuasaan itu.

Eksplorasi yang lain adalah penggunaan multi panggung alias tidak hanya menggunakan satu panggung saja. Dalam DOR, Putu memakai konsep tiga atau empat panggung. Konsep ini ternyata membuat naskah yang ditampilkan menjadi lebih hidup. Selain itu, penggunaan multi panggung adalah manifestasi dari keadilan yang mempunyai banyak wajah. Betapa pencarian akan keadilan bisa sangat riuh dengan berbagai kepentingan. Masingmasing tokoh atau karakter bisa menempati panggungnya sendiri dan harus berusaha keras mempertahankan posisinya sesuai dengan jalannya cerita. Konsep tersebut akan menjadi 
paripurna jika ditambah lagi dengan akting pemain yang matang dan penuh improvisasi dalam menafsirkan teks lakon.

Secara umum, naskah ini adalah naskah yang sangat bagus, walaupun Putu sendiri mengakui masih perlu banyak perbaikan. Suasana teror mental yang menjadi kekhasan Putu Wijaya juga masih terasa. Ketegangan atau suspense yang dari awal dimunculkan dalam adegan bisa terjaga dengan baik hingga akhir cerita. Pembaca naskah lakon pun tidak terlalu kesulitan untuk mencerna jalan cerita yang ada meskipun tanpa harus menonton pertunjukannya. Terlepas dari hal tersebut, Putu Wijaya telah berhasil membuat naskah ini menjadi salah satu adikaryanya. Sesuatu hal yang sampai sekarang masih sulit dikejar oleh penulis naskah lakon masa kini, apalagi melampaui kualitas seorang Putu Wijaya.

\section{Simpulan}

$D O R$ karya Putu Wijaya adalah sebuah refleksi pada fenomena sosial dan hukum yang terjadi di Indonesia. Meskipun ditulis berpuluh tahun yang lalu, DOR masih terasa relevan dengan kondisi masyarakat, terutama kaitannya dengan dunia penegakan hukum dan pencarian keadilan, yang semakin suram dan tidak jelas.

Sebagai sebuah karya seni, DOR mampu memotret berbagai macam fenomena dunia hukum dengan dengan segala silang sengkarutnya. Perbenturan watak atau karakter tokoh betul-betul mewakili segala kompleksitas permasalahan hukum yang ada di Indonesia. Di mana berbagai kepentingan turut andil dalam penentuan atas hasil-hasil pencarian keadilan.

Eksplorasi dan eksperimen Putu Wijaya dalam naskah lakon ini bukanlah sekadar untuk tujuan estetika belaka. Eksplorasi dan eksperimen dalam DOR telah diperhitungkan dengan matang dan akan selalu relevan sepanjang penegakan hukum masih tidak maksimal dan ideal di Indonesia.

\section{Daftar Pustaka}

Aston, Elaine dan George Savona, 1991, Theatre as Sign-System: A Semiotic Text and Performances. London and New York: Routledge

Dipayana, Ags. Arya (ed). 2004. "Warisan Roedjito" dalam Warisan Roedjito: Sang Maestro Tata Panggung, Perihal Teater dan Sejumlah Aspeknya. Jakarta: Dewan Kesenian Jakarta. 
Dewojati, Cahyaningrum. 2010. Drama: Sejarah, Teori, dan Penerapannya. Yogyakarta: Gadjah Mada University Press.

Eddy, Nyoman Tusthi. 1991. Kamus Istilah Sastra Indonesia. Yogyakarta: Kanisius.

Eneste, Pamusuk. 1994. Kamus Sastra Untuk Pelajar. Flores: Nusa Indah.

Sugihastuti dan Suharto. 2002. Kritik Sastra Feminis, Teori dan Aplikasinya. Yogyakarta: Pustaka Pelajar.

Waluyo, Herman J. Prof. Dr. 2002. Drama, Teori dan Pengajarannya. Yogyakarta: Hanindita Graha Widya.

Wijaya, Putu. 1993. DOR. Cetakan ke-2. Jakarta: Balai Pustaka.

1982. “Konsep”. Pranala: http://putuwijaya.wordpress.com/1982/11/17/konsep/. Dilihat tanggal 16 Desember 2019, pukul 16.46 WIB. 